Pawłowska Katarzyna ${ }^{1} \mathbb{D}$, Pawłowski Jakub ${ }^{1}$, Mazurek Tomasz² ${ }^{2}$, Aschenbrenner Piotr ${ }^{3}$, Kołodziej Łukasz ${ }^{4}$, Grochulska Agnieszka' ${ }^{1}$

${ }^{1}$ Pomeranian University in Słupsk Faculty of Health Sciences, Department of Physiotherapy and Emergency Medical Services, Słupsk, Poland

${ }^{2}$ Medical University of Gdansk, Faculty of Medicine, Department of Orthopaedics and Kinetic Organ Traumatology, Gdańsk, Poland

${ }^{3}$ Gdansk University of Physical Education and Sport, Faculty of Physical Education, Department of Natural Sciences, Gdańsk, Poland

${ }^{4}$ Pomeranian Medical University in Szczecin, Faculty of Health Sciences, Department and Clinic of Orthopaedics and Kinetic Organ Trauma-

tology, Szczecin, Poland

\title{
Feet deformities in patients with hip osteoarthritis
}

\author{
Corresponding author: \\ Pawiowska Katarzyna, \\ Pomeranian University in Słupsk. \\ Faculty of Health Sciences, \\ Department of Physiotherapy \\ and Emergency Medical Services, \\ Westerplatte 64 Street \\ 76-200 Słupsk, Poland \\ email: pawlowskakatarzyna@interia.eu
}

Medical Research Journal 2019;

Volume 4, Number 2, 67-71

10.5603/MRJ.a2019.0010

Copyright @ 2019 Via Medica

ISSN 2451-2591

\begin{abstract}
Background: The lower limb constitutes a complex motor system consisting of interdependent components. Any feet disorder may cause disturbances in the biomechanics of the entire lower limb and in consequence can lead to joint degeneration and affect gait.

Methods: Participants were divided into two groups. The research group consisted of $n=60$ patients with hip osteoarthritis, aged 52-84 and the control group consisted of $n=32$ individuals without hip osteoarthritis, aged 50-74. A dynamic pedobarographic analysis was conducted using a RSScan $®$ International Footscan system - a two-meter-long plantar pressure platform with an interface box. Upon completion of the measurement, results were printed and foot deformity was assessed using: Wejsflog index, Clarke's angle, hallux Valgus ALFA angle, pronation-supination index.

Results: The research group had a significantly lower mean Wejsflog index compared to the control group (2.32 vs 2.59). Results showed also that Hallux Valgus ALFA angle was significantly higher and Clarke's angle significantly lower in the research group when compared to the control group.

Conclusions: Foot deformities are significantly more common among patients with hip osteoarthritis. Fallen medial longitudinal arch, fallen transverse arch and hallux valgus are factors to consider in prevention and treatment of hip osteoarthritis.

Key words: hip osteoarthritis, feet deformities, pedobarography
\end{abstract}

Med Res J 2019; 4 (2): 67-71

\section{Introduction}

Coxarthrosis is one of the most common diseases of the locomotor system affecting the middle-aged and the elderly with the onset most often occurring in the fifth and sixth decade of life [1, 2]. Factors affecting the course and the development of osteoarthritis (OA) can be categorised into the following groups: mechanical, genetic, metabolic, inflammatory and immunologic [3, 4]. Chondrocyte activity depends significantly on mechanical stress [5]. Hip dysplasia is a primary example of mechanically induced osteoarthritis. Yet, Perthes disease, slipped capital femoral epiphysis, acetabular protrusion or femoral head avascular necrosis also share the mechanical origin of OA [6]. It should be stressed that physical activity significantly contributes to the pathogenesis of OA when it is of high intensity. It leads to increased catabolism in the cartilage and thus its degeneration, i.e., collagen network weakening, loss of proteoglycans and decrease in cartilage rigidity and flexibility [7].

The lower limb constitutes a complex motor system consisting of interdependent components, among which the feet are of paramount importance, having evolved in the course of phylogenesis to carry significant weight. Any feet disorder may cause disturbances in the biomechanics of the entire lower limb. The gait becomes anomalous and the joints operate in unsuitable conditions. The resulting compensatory mechanisms and suboptimal biomechanics accelerate the degenerative changes. Hence, it may be hypothesised that a significantly higher incidence of feet deformities is to be found in patients with hip osteoarthritis. 
Table 1. Group characteristics

\begin{tabular}{|c|c|c|c|c|c|c|c|}
\hline & \multicolumn{3}{|c|}{ Control Group } & \multicolumn{3}{|c|}{ Research Group } & \multirow[b]{2}{*}{$p<0.05$} \\
\hline & $\mathbf{N}$ & & SD & $\mathbf{N}$ & & SD & \\
\hline Age & 32.00 & 60.56 & 6.65 & 60.00 & 67.57 & 7.86 & $0.00254^{*}$ \\
\hline Weight [kg] & 32.00 & 71.80 & 12.31 & 60.00 & 77.79 & 12.07 & $0.01956^{\star}$ \\
\hline Height [cm] & 32.00 & 164.75 & 8.29 & 60.00 & 164.20 & 7.17 & 0.34462 \\
\hline BMI [kg/m²] & 32.00 & 26.42 & 3.97 & 60.00 & 28.80 & 4.22 & $0.00062^{*}$ \\
\hline
\end{tabular}

\section{Subject, materials and methods}

The research was conducted in 2014-2015 in the Physical Effort and Sports Genetics Laboratory at Gdansk University of Physical Education and Sport. This research did not receive any specific grant from funding agencies in the public, commercial, or not-forprofit sectors.

Participants were divided into two groups. The research group consisted of $n=60$ patients with hip osteoarthritis, aged 52-84 (mean 67,57, SD 7,86) and the control group consisted of $n=32$ individuals without hip osteoarthritis, aged 50-74(mean 60,56, SD 6,65). Table 1 presents sample characteristics.

A dynamic pedobarographic analysis was conducted using a RSScan ${ }^{\circledR}$ International Footscan system - a two-meter-long plantar pressure platform with an interface box. The system consists of 16,384 sensors and has a scanning rate of $500 \mathrm{~Hz}$. The participants were asked to walk barefoot across the platform. Owing to a runway attached to the platform, the participants were not aware of the exact moment of measurement. The measurement was considered valid when both feet were placed on the platform and their scan appeared on the screen.

\section{Patients selection procedure}

Patients were chosen after clinical examination and hip X-Ray conducted by the main doctor. Subsequently, they were selected by inclusion and exclusion criteria. All patients also signed an informed consent form. Research inclusion criteria involved: diagnosed unilateral hip osteoarthritis, age 50-85 and consent for research. Research exclusion criteria were: diagnosed bilateral hip osteoarthritis, rheumatoid arthritis, osteoarthritic changes in the joints of the knee, ankle or foot, any pain reported in the joint of the knee, ankle or foot, past joint replacement or other surgical interventions in the lower limb, changed anatomy of the lower limb (i.e.varus and valgus knee deformities), mobility aid, deep vein thrombosis, acute radiculopathy and lower limb length discrepancy $>1 \mathrm{~cm}$.

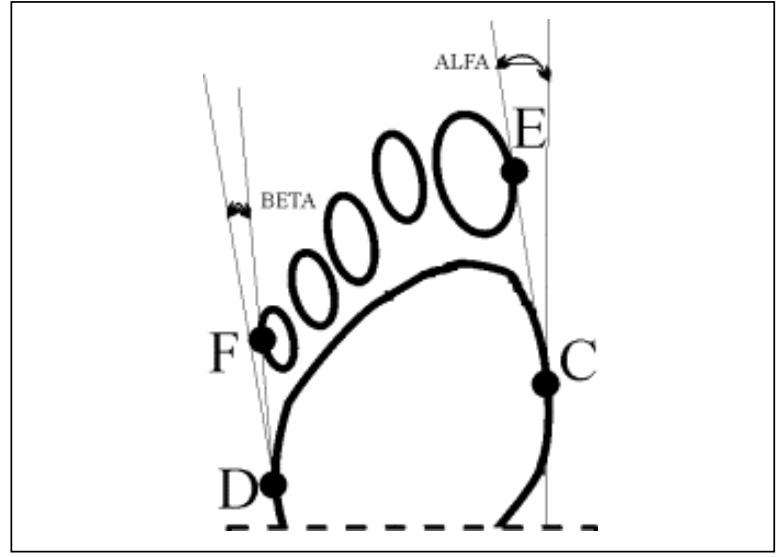

Figure 1. Definition of Wejsflog Index [22]

\section{Determination of used angles}

Upon completion of the measurement, results were printed and foot deformity was assessed using:

1. Wejsflog index,

2. Clarke's angle,

3. Hallux Valgus ALFA angle,

4. Pronation-supination index (calculated by the software).

The parameters were calculated for both feet only for the control group. The research group was recording the side affected by hip OA.

To calculate Wejsflog index, the length (the AB line) and width of the foot (the CD line) were measured, as shown in Figure 1. Subsequently, the length-to-width ratio (normally, 3:1) was calculated [8, 9].

The cut-off value for a normal foot arch was defined as $\geq 2.56$. A Wejsflog index $\leq 2.55$ indicates a fallen arch.

Clarke's angle is defined at the intersecting tangents to points $\mathrm{CS}$ and $\mathrm{qQ}$, as shown in Figure 2 .

Based on the angle value, the following categories were defined:

1. $\leq 30^{\circ}-$ pes planus

2. $31-41^{\circ}-$ low arch

3. $42-54^{\circ}-$ normal arch

4. $\geq 55^{\circ}-$ high arch [10]. 


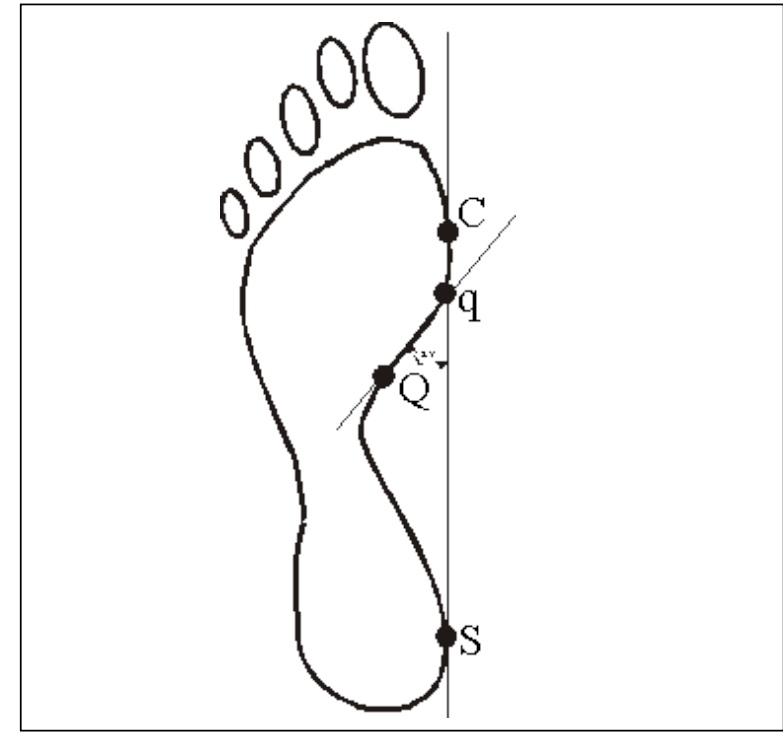

Figure 2. Definition of Clarke's Angle [22]

To assess hallux valgus, the angle between intersecting tangent to the medial foot outline and the tangent running through points $C$ (the medial end of the foot width) and $E$ (medial toe outline) was measured, as shown in Figure 3. It was assumed that the $0-9^{\circ}$ angle indicates a normal position.

External rotation angle for the stance phase was also calculated.

\section{Statistical analysis}

Shapiro-Wilk test was used for data distribution, and non-parametric U-Mann Whitney test was used for comparing means in independent samples.

In order to increase reliability, the median and quartile deviation $Q$ were calculated. In this way, extreme values that could bias the results were eliminated. Quartile deviation is one-half the difference between the first and the third quartiles, that is $25 \%$ and $75 \%$ of results sorted in the ascending order [11].

Significance level (accepted probability level of making a type I error) was set at $\alpha=0,05$.

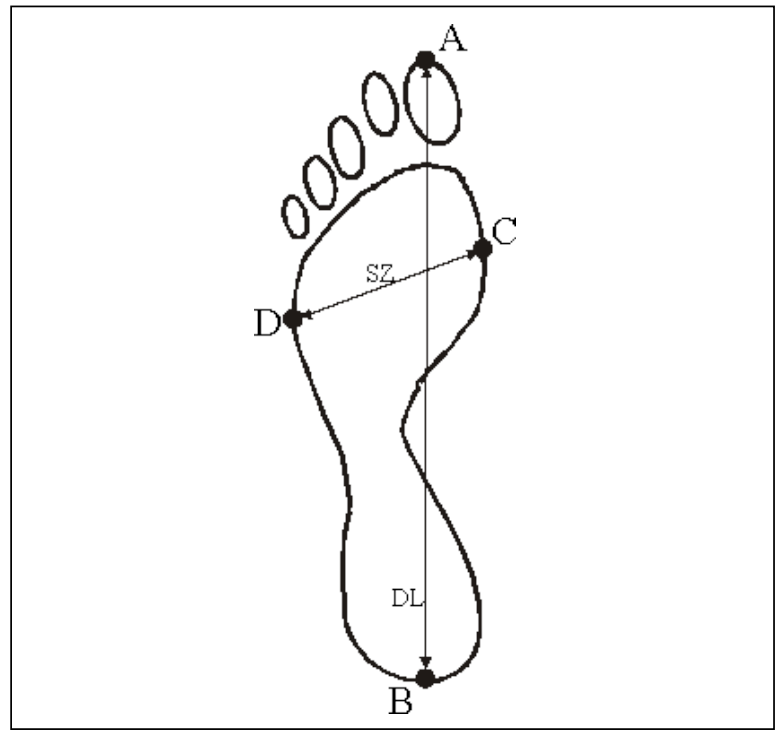

Figure 3. Definition of Hallux Valgus ALFA Angle [22]

\section{Results}

U-Mann Whitney test has shown a statistically significant difference between the research group and the control group for Wejsflog index, Clarke's angle and Hallux Valgus ALFA angle.

The research group had a significantly lower mean Wejsflog index compared to the control group (2.32 vs. 2.59). The index was falling together with the fall of the transverse arch of the foot.

Hallux Valgus ALFA angle was significantly higher in the research group (mean at $13.87^{\circ}$ ) when compared to the control group (mean at $8.85^{\circ}$ ). Significant differences between groups were found in the Clarke's angle, which is used to assess the longitudinal arch. The control group had a mean angle of $52^{\circ}$, which falls into the normal range. The research group, in turn, had a mean angle of $39^{\circ}$ indicative of low longitudinal arch.

External rotation (eversion) angle during the stance phase was also significantly different between the two groups. The research group had an eversion mean of $19.49^{\circ}$ compared to half that angle $\left(10.16^{\circ}\right)$ in the control group. The results are shown in Table 2.

Table 2. Comparison of Wejsflog Index, Clarke's Angle, Hallux Valgus ALFA Angle and External Rotation Range between control and research groups

\begin{tabular}{|c|c|c|c|c|c|c|c|}
\hline & \multicolumn{3}{|c|}{ Control Group } & \multicolumn{3}{|c|}{ Research Group } & \multirow[b]{2}{*}{$p<0.05$} \\
\hline & & & $\mathbf{Q}$ & & & $\mathbf{Q}$ & \\
\hline Wejsflog Index & 2.59 & 2.6 & 0.20 & 2.32 & 2.30 & 0.16 & $0.0000^{*}$ \\
\hline Clarke Angle $\left[{ }^{\circ}\right]$ & 52.23 & 52.00 & 6.375 & 39.00 & 35.00 & 11.00 & $0.0000 *$ \\
\hline Hallux Valgus ALFA Angle $\left[^{\circ}\right]$ & 8.85 & 7.50 & 7.50 & 13.87 & 10.00 & 7.50 & $0.0306^{*}$ \\
\hline External Rotation Range $\left[^{\circ}\right]$ & 10.16 & 11.46 & 3.8325 & 19.49 & 18.375 & 5.8 & $0.0000^{*}$ \\
\hline
\end{tabular}




\section{Discussion}

Data collected in multiple studies show that as many as $80 \%$ of the adult population may suffer from foot disorders, which are often diagnosed already in childhood. Foot or toes disorder erodes the lower limb activity and function. Abnormalities in the structure or biomechanics trigger changes of function up to the kinetic chain of the lower limb and the axial skeleton. Shifts in the stance pattern changed the centre of gravity and deviated gait pattern leads to OA changes that are secondary to such non-physiological wear and tear process [12].

Pes planus is one of the most common postural deformities affecting the motor system often with positive feedback that leads to further anatomic changes in the foot, i.e. pes valgus, excessive foot pronation and abduction of the forefoot. Pathomorphological changes, such as pathology of connective tissue or Achilles tendon shortening may also occur $[13,14]$.

According to Dziak, pathologies of the knee and the hip may stem from changes of the foot that occurred in childhood and went unnoticed [15].

A noteworthy contribution to the subject was the research conducted by Rongies et al. investigating the incidence of pes planus in relation to coxarthrosis and gonarthrosis. A total of 76 patients were divided into 3 groups: $A$ - patients with gonarthrosis, $B$ - patients with coxarthrosis and the control group. Based on the results, it was found that pes planus and low longitudinal arch were significantly more common in participants with coxarthrosis and gonarthrosis when compared to the control group. Mean Clarke's angle in group B was $32^{\circ}$ [16]. These findings correspond with our results since the Clarke's angle in our research group was $39^{\circ}$. Both values fall into the category of low foot arch (between $31^{\circ}$ and $41^{\circ}$ ) [16].

Rzaniak et al. conducted research that lays the further ground for the coexistence of a fallen longitudinal arch with OA of the knee or the hip. The authors compared 27 patients with coxarthrosis with 27 healthy controls. Clarke's angle was measured for all participants. The study concluded that patients with coxarthrosis had a significantly lower Clarke's angle compared to the control group [17], which is in line with our findings.

Lorkowski points out that primary coxarthrosis must be a result of some specific mechanical factors. He points that a fallen longitudinal arch causes increased the contact area between the foot and the ground, which affects the distribution of loading forces in the joints above. Thus, according to Lorkowski, such altered mechanics in the transfer of weight from the proximal joints, via the feet, towards the ground, may lead to arthrosis [18].

Similarly, von Grabowski found that accelerated wear of the knee joint stems from inborn or acquired lower limb axis deviation [19].
Research also confirms observations made by Cavanagh who believes changes in the height of the foot arch determine the posture, which may contribute to the development of locomotor pathology. Cavanagh argues that normal foot anatomy is indispensable for proper locomotion. Therefore, neglecting fallen arches in childhood results in the development of deformities in adulthood. Cavanagh stresses that even the smallest deformity may trigger changes in the locomotor system, while abnormalities in the longitudinal arch have the most far-reaching consequences in the biomechanics chain of the leg. This, in turn, may cause abnormalities of the stance, gait, development of arthrosis and pain, even in distant joints such as the vertebral column [12].

Evidence for the extended impact of a foot fallen arch on the locomotor system has been provided by Skura et al. in their study consisting of 370 women and 514 men sampled randomly. The results have shown that a fallen arch coincides not only with coxarthrosis and gonarthrosis but also with disorders of the ankle joints, sacroiliac joints and the lumbar spine [20].

In our study, we have used Wejsflog index to assess the degree of the transverse arch of the foot for both groups. Statistical analysis has shown a significant difference in Wejsflog index between the research group (2.32) and the control group (2.59).

Wantabe et al. stress that fallen arch is a complex of deformities such as low longitudinal arch, pes valgus and abduction of the forefoot. Authors also note that tibialis posterior dysfunction is a common cause of acquired pes planus, which remains flexible up to stage II of dysfunction when the deformity is passively correctable. Such findings have been widely discussed in the literature in the past 20 years [21].

A fallen transverse arch may often be associated with hallux valgus. In this study, we have observed a significant difference in the mean Hallux Valgus ALFA angle between the research group $\left(13.87^{\circ}\right)$ and the control group $\left(8.85^{\circ}\right)$.

\section{Conclusions}

1. Foot deformities are significantly more common among patients with hip osteoarthritis.

2. Fallen medial longitudinal arch, fallen transverse arch and hallux valgus are factors to consider in prevention and treatment of hip osteoarthritis.

\section{Acknowledgements}

Authors would like to thank manager Ms Danuta Dworakowska and coordinator of scientific studies prof. Stanisław Sawczyn PhD for the possibility to use the 
equipment of Physical Effort and Genetics Laboratory at the Gdańsk University of Physical Education.

This research did not receive any specific grant from funding agencies in the public, commercial, or not-for-profit sectors

\section{Conflict of interest}

The authors of this paper have no financial or personal relationships with other people or organizations that could inappropriately influence (bias) our work.

\section{REFERENCES}

1. Aronson J. Osteoarthritis of the young adult hip: etiology and treatment. Instr Course Lect. 1986; 35: 119-128, indexed in Pubmed: 3819398.

2. Hoaglund FT, Steinbach LS. Primary osteoarthritis of the hip: etiology and epidemiology. J Am Acad Orthop Surg. 2001; 9(5) 320-327, doi: 10.5435/00124635-200109000-00005, indexed in Pubmed: 11575911.

3. Creamer P, Hochberg M. Osteoarthritis. Lancet. 1997; 350(9076) 505-9.

4. Goldring MB, Goldring SR. Osteoarthritis. J Cell Physiol. 2007: 213(3) 626-634, doi: 10.1002/jcp.21258, indexed in Pubmed: 17786965.

5. Guilak F, Hung C. Physical regulation of cartilage metabolism. In: Basic Orthopaedic Biomechanics and Mechanobiology. Ed. Mow VC Huiskes R. Lippincott, Williams \& Wilkins. Philedalphia. In: Mow VC, Huiskes RL. ed. Basic Orthopaedic Biomechanics and Mechanobiology. Williams \& Wilkins, Philedalphia. USA 2004: 259-300.

6. MacGregor AJ, Antoniades L, Matson M, et al. The genetic contribution to radiographic hip osteoarthritis in women: results of a classic twin study. Arthritis Rheum. 2000; 43(11) 2410-2416, doi: 10.1002/1529-0131(200011)43:11<2410::AID-ANR6> 3.0.CO;2-E, indexed in Pubmed: 11083262.
7. Griffin TM, Guilak F. The role of mechanical loading in the onset and progression of osteoarthritis. Exerc Sport Sci Rev. 2005; 33(4): 195-200, doi: 10.1097/00003677-200510000-00008, indexed in Pubmed: 16239837

8. Rykała J, Snela S, Drzał-Grabiec J, et al. Ocena wysklepienia podłużnego i poprzecznego stóp w warunkach odciążenia i obciążenia masą własną u dzieci w wieku 7 - 10 lat. Prz Med Uniw Rzesz Inst Leków. 2013; 2: 183-93.

9. Kasperczyk T. Wady postawy ciała. Wydawnictwo Kasper. Kraków, PL. ; 1994: In

10. Krupicz B. Wady stóp: biomechanika, diagnostyka, leczenie. Wydawnictwo Politechniki Białostockiej. Białystok, PL. ; 2008: In.

11. Petrie A, Sabin C. Statystyka medyczna w zarysie. Wydawnictwo Lekarskie PZWL, Warszawa 2006

12. Cavanagh PR, Henley JD. The computer era in gait analysis. Clin Podiatr Med Surg. 1993; 10(3): 471-484, indexed in Pubmed: 8364850.

13. Lorkowski J. Porównanie badania planokonturograficznego i dynamicznego badania pedobarograficznego w ocenie stopy płaskie u dzieci. Scr Period. 2000; 2(3): 894-7.

14. Szczygieł E, Golec E, Golec J, et al. Analiza porównawcza dystrybucj nacisków na powierzchni podeszwowej stóp prawidłowo wysklepionych oraz stóp plaskich. Przegl Lek. 2008; 65(1): 4-7.

15. Dziak A. Anatomia stopy. . PWSZ, Chorzów 1973: In

16. Rongies W, Bąk A, Lazar A, et al. Próba wykorzystania badania pedobarograficznego do oceny skuteczności rehabilitacji u osób z choroba zwyrodnieniowa stawów biodrowych. Ortop Traumatol Rehabil. 2009; 11(3): 242-52.

17. Rzaniak E, Dzierżanowski M, Mątewski D, et al. Wpływ zmian zwyrodnieniowych stawów biodrowych na ukształtowanie stopy. Kwart Ortop. 2007: 3: 342-51.

18. Lorkowski J. Ocena rozkładu nacisków na podeszwowej stronie stóp u chorych ze zmianami zwyrodnieniowymi stawów biodrowych. . Ortopedia i Traumatologia u Progu Nowego Millenium, Bydgoszcz 2002.

19. Von Gr, Palme E, Von Gr. Analiza różnych czynników etiologicznych mogących sprzyjać powstaniu gonartrozy w grupie 320 chorych leczonych alloplastyka stawu kolanowego. Ortop i Traumatol u progu nowego Millenium , Bydgoszcz 2002: 271-2.

20. Skura A, Grzywa M, Kaczmarczyk F. Ocena wpływu płaskostopia na inne narządy ruchu. Med Ogólna. 1996; 2(4): 370-81.

21. Watanabe K, Kitaoka HB, Fujii T, et al. Posterior tibial tendon dysfunction and flatfoot: analysis with simulated walking. Gait Posture. 2013; 37(2): 264-268, doi: 10.1016/j.gaitpost.2012.07.015, indexed in Pubmed: 22939754.

22. Internet. http://www.cq.com.pl/n_st_parametry.html (29.11.2018 r). 